\title{
A Limited Clinical Trial of Injectable Thiambutosine
}

\author{
(Ciba I 906)
}

\author{
S. G. BROWNE, M.D., F.R.G.P., F.R.G.s., D.T.M. \\ Leprosy Service Research Unit, Uzuakoli, Eastern Nigeria
}

The inconvenience and expense of giving thiambutosine orally two or three times a day, coupled with the fact that a variably high proportion of the drug is not absorbed from the digestive tract, have stimulated the search for a method by which the drug can be given at less frequent intervals, at a lower dosage and with a higher utilization ratio.

To this end, Messrs Ciba Limited, of Basle, the makers of thiambutosine, a proprietary diphenyl-thiourea (Ciba I 906, or 'DPT'), have prepared a 20 per cent suspension of their product in arachis oil. Experimental studies in the mouse have shown that this concentration of the drug in this vehicle is well tolerated locally and systemically. The active product is gradually released over a period of two to three weeks.

\section{Patients}

For this small pilot study, four untreated patients were selected - two had lepromatous leprosy, and two bacteriologically positive borderline leprosy. Their weights ranged from Ioo to I 27 lbs.

\section{Dosage}

For I8 months, fortnightly injections of io ml. of the 20 per cent oily suspension were given into the quadriceps extensor femoris, a different site being used on each occasion. Careful injection technique included cleaning the site with an alcohol-impregnated swab; a slow, steady injection; complete injection of the product before withdrawal of the needle; prolonged and gentle massage of the site.

At this point, the injections were discontinued and dapsone was substituted, beginning with I oo mgm. twice weekly for three weeks, increasing to $200 \mathrm{mgm}$. twice weekly for three weeks, and thereafter $300 \mathrm{mgm}$. twice weekly.

\section{Local tolerance}

Local tolerance was perfect. The injections were virtually painless. Some patients complained of very slight and transient 'heaviness' at the injection site. No infection or abscess was seen, and no oozing of the injected material from the needle-puncture.

\section{General tolerance}

No systemic toxic symptoms were reported.

Results

Results were comparable with those of thiambutosine administered orally.

\section{Clinical improvement}

Clinical improvement was noted in all patients, being most marked in the two with borderline leprosy. This improvement was continuous. The patient showing least improvement was an old man with advanced nodular lepromatous disease.

\section{Bacteriological improvement}

The bacteriological improvement ran pari passu with the clinical progress. Normal-staining solid rods of $M$. leprae, which had been present in the following approximate percentages in the four patients: 6o, 6o, Ioo, 8o, disappeared finally from all eight sites smeared after the lapse of $\mathrm{I} 5$, nine, five and three months respectively. The reduction in the Bacterial Index was 8I per cent at the end of the 18 months of thiambutosine therapy.

Substitution of dapsone for injectable thiambutosine was accomplished without incident, and progress thereafter was maintained at approximately the same rates as before. 


\section{'Resistance'}

In spite of the progressive reduction in the Bacterial Index, normal-staining solid rods began to reappear in the nasal mucosa of the one patient referred to above, two months before the cessation of thiambutosine treatment, i.e. during the i6th month. These persisted and became proportionately more numerous, eventually attaining an average of 22 per cent of the total number of recognizable bacilli present in the smears from the nasal mucosa. Smears of the ear-lobes and then of some skin sites showed normal forms, which, however, never exceeded Io per cent of the total. Then, during the i 8 th and igth months, the Bacterial Index rose from 0.9 to 2.5 and remained above 0.9 for I o months. By the end of 30 months of treatment (i.e. I 8 months of injectable thiambutosine followed by I 2 months of dapsone), the Bacterial Index and the Morphological Index (= the percentage of solid-staining rods) had both returned to the level existing at the i 6 th month.

\section{Reaction}

Neither of the two lepromatous patients experienced erythema nodosum leprosum, and no patient developed peripheral neuritis while under treatment with injectable thiambutosine or while subsequently taking dapsone orally.

\section{Conclusions}

The therapeutic effect of injectable thiambutosine appears to be comparable with the orally administered product.
In this small series, local tolerance was excellent, but the possibility must be taken into account of separation of the drug from its vehicle and its concentration at the periphery of the injected suspension. There are certain practical difficulties inherent in the injection of a viscid liquid in doses of the order of ro $\mathrm{ml}$. fortnightly, which must be recognized when contemplating mass treatment.

There is a restricted area of usefulness for a well-tolerated injectable alternative to dapsone.

The development of 'resistance' during the second year of administration of injected thiambutosine recalls its occurrence after oral administration of the product.

S UMMAR Y

Ten ml. of a 20 per cent suspension of thiambutosine (Ciba I906) in arachis oil was given intramuscularly at fortnightly intervals for i 8 months to a group of four patients. The injections were well tolerated. The clinical and bacteriological improvement noted was on a par with that in similar patients taking the drug orally.

\section{A GKNOWLEDGEMENTS}

I wish to express my thanks to Messrs Ciba Limited, for supplies of injectable thiambutosine (Ciba I906), and for providing experimental evidence and references, and to Dr S. O. Egwuatu, Chief Medical Officer, Ministry of Health, Eastern Nigeria, for permission to publish this article. 